\title{
Reduction of fluid migration in well cement slurry using nanoparticles
}

\author{
Mahmoud Bayanak ${ }^{1}$, Soroush Zarinabadi ${ }^{2,}{ }^{*}$, Khalil Shahbazi $^{3}$, and Alireza Azimi ${ }^{1}$ \\ ${ }^{1}$ Department of Chemical Engineering, Mahshahr Branch, Islamic Azad University, Mahshahr, Iran \\ ${ }^{2}$ Department of Engineering, Ahvaz Branch, Islamic Azad University, Ahvaz, Iran \\ ${ }^{3}$ Department of Petroleum Engineering, Petroleum University of Technology, 63146-61118 Ahvaz, Iran
}

Received: 6 December 2019 / Accepted: 3 June 2020

\begin{abstract}
One of the main problems during oil well completion and cementing operation is fluid migration through cement bulk or behind the cemented casing. Slurry composition and characteristic have been focused and improved in last decades to mitigate gas migration and, recently, aspects such as using nanotechnology have been investigated to amend the conditions. In this research, two moderate base slurries with 95 and 120 Pound per Cubic Feet (PCF) densities containing different percentages of nanosilica have been examined using a perfect test package. The results of Fluid Migration Analyzer (FMA) demonstrated that using correct percentage of nanosilica particles modified rheological behavior of the slurries and decreased fluid migration volume. Moreover, adding nanoparticles did not have any negative effects on any conventional parameters. However, static gel strength analyzer showed significant transient time reduction which is an important key in cement setting profile. Triaxial test results together with Mohr circles analyzing presented considerable progress in cement stability and compressive strength.
\end{abstract}

\section{Nomenclature}

CS Compressive Strength

FLC Fluid Loss Controller

FMA Fluid Migration Analyzer

PCF Pound per Cubic Feet

PV Plastic Viscosity

SGSA Static Gel Strength Analyzer

UCA Ultrasonic Cement Analyzer

YP Yield Point

$\Theta \quad$ Dial reading at viscometer (rotational speed)

\section{Introduction}

Oil and gas industry and drilling a well are costly industries. There are various vital reasons for cementing operation such as supporting and holding the casing, isolate the formation, in which fluid migration through cement slurry, as one of the most dangerous and complicated challenges faces drilling industry has been occurred. This phenomenon has become a global problem with its disastrous effects. Immediate, short term and long term are the three types

\footnotetext{
* Corresponding author: soroushzarinabadi@iauahvaz.ac.ir
}

of gas migration based on the lifecycle of the well. There are different strategies to prevent gas migration, each type of migration has special strategies. In this research the short-term gas migration has been studied. This type of migration which is usually referred to as post-placement migration, is observed between the final step of the primary cementing job (usually highlighted by the plug landing) and the cement setting step. However, the procedure which triggers the migration is assumed to be the annular pressure decay $[1,2]$. Thousands of research and millions of dollars spent on understanding the mechanics of fluid (especially gas) migration and developing solutions, it leads to a wide range of different strategies that describe different aspects of gas migration phenomena [3]. Experimental investigation and case studies to provide practical advice [4-7], technical solution development [8-13], application of different cement additives in cement slurry [14-17] and prediction technique for cement quality [18-20] are number of strategies studied by researchers. All the approaches and strategies utilized to minimize the gas migration risks primarily rely on targeting one or multiple gas migration conditions, including the control of annular pressure decline, reduction of gas entry space, and ultimately minimizing the migration path. Nanotechnology has the ability to offer effective changes in several areas of oil and gas industry such as exploration, drilling, cementation, production, etc. Use of nanotechnology in the cement slurry can 
also achieve solutions to some of the problems pertaining to oil well cementation [21]. Cementing engineering is one of the most applicable considerations in drilling industry where it faces harsh and severe environments with difficulties in temperature and pressure controls [22]. This research is focusing on fantastic remedies for cementing characteristics with great attention on its inherent properties with great capacities of nanotechnology. It should be mentioned that right after first observation of gas migration issue in oil wells, especially in five recent decays, hundreds studies have been carried out for evaluation and cure this problem [23]. All aspects of gas migration have been discussed in literature. Al-Buraik et al. explained about history and experimental aspects of gas migration [7]. Some recommendations and guidelines were represented by Dean and Brennen [24]. Ahmed et al. evaluated effects of using chemical additives on gas migration [25]. Wilkins and Free demonstrated valuable techniques for gas migration prediction on oil and gas wells [20]. Abbas et al. generally pointed out that annular gas migration after placement of cement, has been identified as one of most considerable subjects in the oil and gas industry for many years [26]. Although King and King illustrated that annular gas migration issues were initially recognized in the mid-1960 during cementing operations of gas wells [27]. Another way for optimization of gas migration is using the expanding cements for better bonding of cement in the contact area of cement-casing and cement-formation. A paper that comprehensively addressed this issue was published by Griffin et al. [28]. In that paper, a special system of expanded cement is proposed that provides an ideal condition for cement bonding [28]. In another great research, fundamental factors were evaluated and studied for their effects on cementing that summarized as heat, pressure, slurry weight, particle size, and finally volume fraction of constituents [29]. In 2003, Goboncan and Dillenbeck discussed about cement-shrinkage and proposed that in theoretical side of view shrinkage happened with two states of overall shrinkage and porosity in cement matrix [30]. Also, Mata and Calubayan presented that usage of low density cements based on the hollow glass spheres, can weaken probability of gas migration in weak formations [31]. In 2016, Al-Yami and Al-Humaidi could greatly reduce the amount of gas migration behind the casing with the invention of a cement mixture containing silica particles and hematite [32]. Also, in 2015 they could solve a lot of problems faced with drilling of deep wells by designing special cement that performed well at high pressures and temperatures [33]. In 2007, Pour and Moghadasi pointed out that inappropriate control of fluid flow in the South Pars field in Iran has caused the problems of gas migration [34]. As it is approved after injection of the cement slurry to the bottom of the well, it goes up into the gap between the casing and rock formation which shines requirements for especial attention to the isolation of the zone [35]. In this paper, the focus is on the G class cement. Also, cementing behind the casings has several goals, one of the most important is separation of different layers with different pressures and fluids [36-39]. In this engineering branch, setting thickening time (cement slurry becomes solid cement) depends on variety of factors and conditions such as slurry compressive strength, rheological properties, fluid loss and so on. On the other hand, penetration and transfer of fluid from the cement results in the mixing of different layers of fluids and increased probability of eruption [40]. A proposed slurry for a cement operation has several properties that all of them have to be recorded and analyzed before the operation.

In 1977 an upgraded method was offered that during cementing of high pressure zones, the maximum possible value of controller additives should be used to minimize the gas leakage [27]. In 2015, Chinh et al. divulged most oil and gas fields around the world that have reported indications of gas migration in the annulus [40]. Al-Ramadan et al. defined gas migration as the propagation of gas through and around a cemented annulus which leads to the development of a flow path through the annular cement into the surface [41]. In 2017, Lackey et al. reviewed the effect of surface deflection on the integrity of the well and the rate of gas migration. They found that depth of the well was very influential and could greatly control the amount of gas migration [35]. In 2017, Guo et al. conducted a combined laboratory and modeling study to detect the occurrence of gas or mass migration in wells. In the first attempts, they examined these phenomena in different dimensions of circular space and then employed CFD by modeling and studying these phenomena [42]. They offered an experimental research that clarified the most influential and effective approach for introducing a special cement to prevent gas migration.

Although, engineers use some basic data to design cement slurry, but important slurry characteristics that should be investigated for gas migration include density, pre and post heating rheology, deposition and mixing and homogeneity, fluid loss, free water, setting profile, compressive strength, permeability, dewatering, process of increasing resistance of gels and so on. Slurry that does not meet the required specifications for any of these features cannot withstand the gas leakage [43].

Application of nanotechnology can improve cement elasticity, strength, self-cleaning, electrical conductivity, etc. [44]. Santra et al. demonstrated effects of nanomaterials on early cement slurry gelation, compressive strength ratio, viscosity enhancement and early stage compressive strength [45]. Ershadi et al. pointed out those nanomaterials have reduced cement slurry thickening time [46]. Also, Fakoya and Shah discussed application of nanosilica in oil industry and cementing operation. It was illustrated that nanosilica could reduce drag in porous media, has been effective in water invasion in shale, and has been applicable in fluids rheology control [47]. Thakkar et al. [21] have demonstrated application of nanosilica as an alternative for conventional cement additives like calcium chloride and silica. From this point of view, consumption of nanosilica was so smaller than the others, and has been multi-functional. Due to using nanosilica, decreasing in thickening time, increasing in compressive strength and decreasing in fluid loss have been reported. In addition, they have reported (2019) decreasing the Wait On Cement (WOC) time and, therefore, reduction of the overall capital cost of a well due to using of nanosilica [21]. The nanofluid is a fluid species in 
which nanoparticles are dissolved in an approximate diameter of $10 \mathrm{~nm}$ in liquid. The presence of these particles causes the cement pattern to completely change and the way the molecules and layers are located. Therefore, in case of correct selection of this material, it can be obtained at very favorable conditions at a very low cost compared to other methods [43].

In the field of gas migration, a set of methods in different phases should be used. The focus of this study is on the design of cement slurry, which is perhaps the most important and most influential stage in the fight against gas influences. The proper design of cement slurry means optimizing slurry formulation. This optimization means selection with the precision of the additives, along with precision in the short and long term performance of the cement. Formulation evaluations are carried out with sufficient attention to the issue of gas migration, in which effective factors are identified and studied. In this context, a step-by-step program has been developed to design optimum gas-slurry cement slurry. Although the main roots of fluid migration were discussed in this research and the effects of nanosilica on cement slurry have been investigated, this problem needs more attention and further attempts to mitigate whole problem.

According to research of Nelson and Guillot, paths and reduction of hydrostatic pressure in annular space are two main reasons of gas migration in which gas can invade in cemented annular space [36]. Cooke et al. had explained that cement slurry loses the ability to transfer hydrostatic pressure to the formation prior to complete hydration [5]. It means slurry pressure actually decreases after replacement.

If the cement does not have enough resistance to the gas pressure, the formation gases under pressure attack the hydrated cement and create gaseous channels. The fluid attack may not be stopped until the cement has sufficient adhesion strength. Li et al. confirmed that the gas does not penetrate into the cement matrix as long as the slurry pore pressure remains above the formation gas pressure [48].

Optimizing the Particle Size Distribution (PSD) can improve slurry performance with respect to gas migration. By optimizing the PSD, the solid particles can aggregate well. Therefore, a slurry with varying particle size has a higher density than a finite particle size slurry.

As shown in Figure 1, nanosilica particles could fill the voids between the cementitious grains, and hence create a filling effect [49]. They also fill the remainder of the cavities in hydrated and non-hydrated [50]. After the addition of nanosilica to the cement, nucleation sites are provided for cement hydration. Nanosilica particles affect the cement slurry in different ways. They affect thickening time, compressive strength, porosity and permeability within the cement [51].

The results of the experiment showed that nanosilica can improve the structure and reduce the permeability of the hardened concrete [52]. Reducing the permeability in concrete by adding nanosilica was reported by $\mathrm{Li}$ et al. [48]. Gaitero showed that nanosilica particles fill the cavities of the CSH-gel structure and act as the nucleus to firmly attach to the CSH-gel particles [53, 54]. According to Ershadi et al., Adding 1\% nanosilica to the slurry reduced the porosity and permeability by 33 and $99 \%$, respectively [46].

\section{Experimental}

\subsection{Material and method}

Nanosilica $\left(\mathrm{SiO}_{2}\right.$ with $99 \%$ purity and $50-60 \mathrm{~nm}$ in diameter) made by "Nanoshell' Company (USA), G-class cement (API standards, from Delijan Company, Iran), water, dispersants, fluid loss controls, retarders, gas migration additive, antifoam, and extender were employed. Most of cement additives have trade name. For example, extender D-124 is a material composed of hollow spheres of aluminosillicate with a specific gravity lower than water. The particle size, similar to silica flour, enables blending the material with cement to form a slurry with density as low as $9.0 \mathrm{Lb}$./Gal. Two main slurries with densities of $90 \mathrm{PCF}$ and $120 \mathrm{PCF}$ were used. Slurries with $95 \mathrm{PCF}$ weight were shown as condition 1 and slurries with 120 PCF weight were shown with condition 2. Table 1 summarizes all corresponding data.

\subsection{Experiments procedure and apparatus}

The process of testing is started with an initial designing of slurry formula and all tests were performed according to the proposed programs as depicted in the above table. The considered slurry was used in a "7 inch" liner where gas migration had been reported after its setting.

For conducting experiments in this project, required apparatus are listed as: SGSA, UCA, FMA, mixer, mud scale, statistic filter press, pressure and atmospheric consistometer and finally triaxial strength measurement apparatus. The process of carrying out experiments was begun with a slurry designed with initial formulation. As it has been illustrated that due to instant gelation and rapid setting, more than $1 \%$ of nanosilica cannot be used, it was decided to test percentages such as $0.55,0.33,0.22$, and 0.11 . In this case, the apparent outcomes were more appropriate and additional and custom tests were planned. By deepening the experiments, it was gradually determined that the optimal percentage of nanosilica as an effective additive for reducing fluid migration was achieved.

\subsection{Diagnostic tests}

The two slurries which are formulated and prepared based on the above aforementioned details should be tested and evaluated for their performance during cementing. So, in the case of the rheology test, they were prepared and weighted to be sure about their densities and compositions. Thereafter, rheology tests were performed for the two types of slurries and then PV and YP were calculated based on the following formulas:

$$
\begin{gathered}
\text { Plastic Viscosity }(\mathrm{PV})=\left(\theta_{300}-\theta_{100}\right) \times 1.5, \\
\text { Yield Point }(\mathrm{YP})=\theta_{300}-\mathrm{PV} .
\end{gathered}
$$




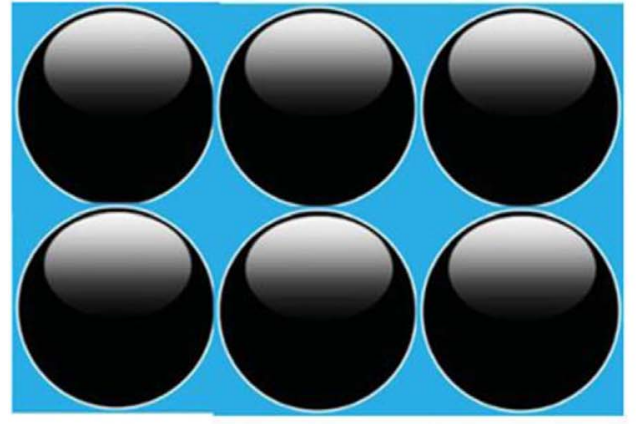

(a) Conventional cement slurries

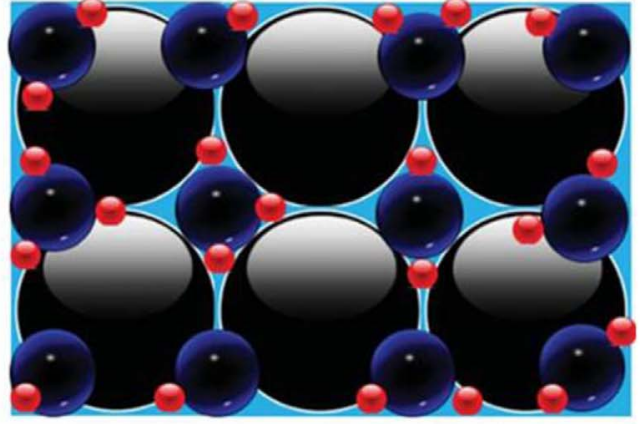

(b) Particle size optimization slurries

Fig. 1. Cement matrix compressibility.

Table 1. Understudy slurry cement properties and compositions.

\begin{tabular}{lccccccccccc}
\hline \multicolumn{2}{l}{ Slurry composition } \\
\hline Condition & $\begin{array}{c}\text { Density } \\
\text { (PCF) }\end{array}$ & $\begin{array}{c}\text { Cement } \\
\text { G (gr) }\end{array}$ & $\begin{array}{c}\text { D-124 } \\
\text { extender } \\
\text { (gr) }\end{array}$ & $\begin{array}{c}\text { FLC } \\
\text { (gr) }\end{array}$ & $\begin{array}{c}\text { Anti- } \\
\text { gas-mig } \\
\text { (gr) }\end{array}$ & $\begin{array}{c}\text { Nanosilica } \\
\text { percentage }\end{array}$ & $\begin{array}{c}\text { TA-47 } \\
\text { anti- } \\
\text { foam } \\
\text { (gr) }\end{array}$ & $\begin{array}{c}\text { O-R 5 } \\
\text { retarder } \\
\text { (gr) }\end{array}$ & $\begin{array}{c}\text { O-CFR4 } \\
\text { dispersant } \\
\text { (gr) }\end{array}$ & $\begin{array}{c}\text { Water } \\
\text { (mL) }\end{array}$ \\
\hline 1 & A & 95 & 418 & 42 & 0.83 & 0 & 0 & 0.63 & 1.25 & 0.41 & 438 \\
1 & B & 95 & 418 & 42 & 0.83 & 0 & 0.1 & 0.63 & 1.25 & 0.41 & 435 \\
1 & C & 95 & 418 & 42 & 0.83 & 0 & 02 & 0.63 & 1.25 & 0.41 & 430 \\
1 & D & 95 & 418 & 42 & 0.83 & 0 & 0.3 & 0.63 & 1.25 & 0.41 & 425 \\
1 & E & 95 & 418 & 42 & 0.83 & 0 & 0.5 & 0.63 & 1.25 & 0.41 & 420 \\
2 & A & 120 & 802 & 0 & 0 & 81 & 0 & 0.63 & 0 & 0.80 & 269 \\
2 & B & 120 & 802 & 0 & 0 & 81 & 0.1 & 0.63 & 0 & 0.80 & 265 \\
2 & C & 120 & 802 & 0 & 0 & 81 & 0.2 & 0.63 & 0 & 0.80 & 260 \\
2 & D & 120 & 802 & 0 & 0 & 81 & 0.3 & 0.63 & 0 & 0.80 & 257 \\
2 & E & 120 & 802 & 0 & 0 & 81 & 0.5 & 0.63 & 0 & 0.80 & 255 \\
\hline
\end{tabular}

Free water in slurry cement is defined as the water which exists more than needed for the hydration of cement and additives. In this test, the slurry is poured into a $250-\mathrm{mL}$ cylinder and kept immobile for $2 \mathrm{~h}$ after that, the amount of water collected at the top of the slurry is measured. Since fluid loss clarifies water or fluid content that is separated from the slurry during $30 \mathrm{~min}$ of residence time at pressure of $100 \mathrm{psi}$ and ambient temperature, understudy cement slurries were processed based on the API standard for evaluation of their fluid content. As Kleef and Vliet defined, thickening time is the pump able time of cement or the time it takes to begin thickening [55]. As thickening time increases with decreasing in temperature, Soltanian and Mortazavi revealed that by using of nanosilica, cement slurry thickening time has been reduced [56]. Cement compressive strength is the capacity of cement to withstand loads tending to reduce size. Testing the strength of standard cement cubes only provides information about cured strength. To accurately and effectively schedule a cementing job with a minimum WOC time, you need to determine how slurry develops strength over time during curing. The cement slurry was poured into Ultrasonic Cement Analyzer (UCA) for non-destructive test in $24 \mathrm{~h}$. In a nondestructive test, sonic speed is measured through the cement as it sets. This value is then converted into compressive strength. The UCA cell is equipped with a heating jacket, temperature controller, pressure system, cooling system, and transducers and rated at $204{ }^{\circ} \mathrm{C} / 400{ }^{\circ} \mathrm{F}$ and 30000 psi. The system measured the strength development by measuring the speed of the ultrasonic signals being sent through the cement while it sets up. The speed of the signals was calculated and correlated to a compressive strength in psi. Setiati has explained that adding nanosilica to cement slurry results in increasing of compressive strength and density, and improving mechanical properties, especially at low temperature [57]. It has been observed that with increasing weight percent of nanosilica, the compressive strength of the cement increases. However, if the proportion of nanosilica in the cement slurry exceeds some certain amount, there can be a decrease in the compressive strength of cement. In addition, as the last part of the attempt, in order to evaluate the performance of the cement 
Table 2. Samples condition and properties.

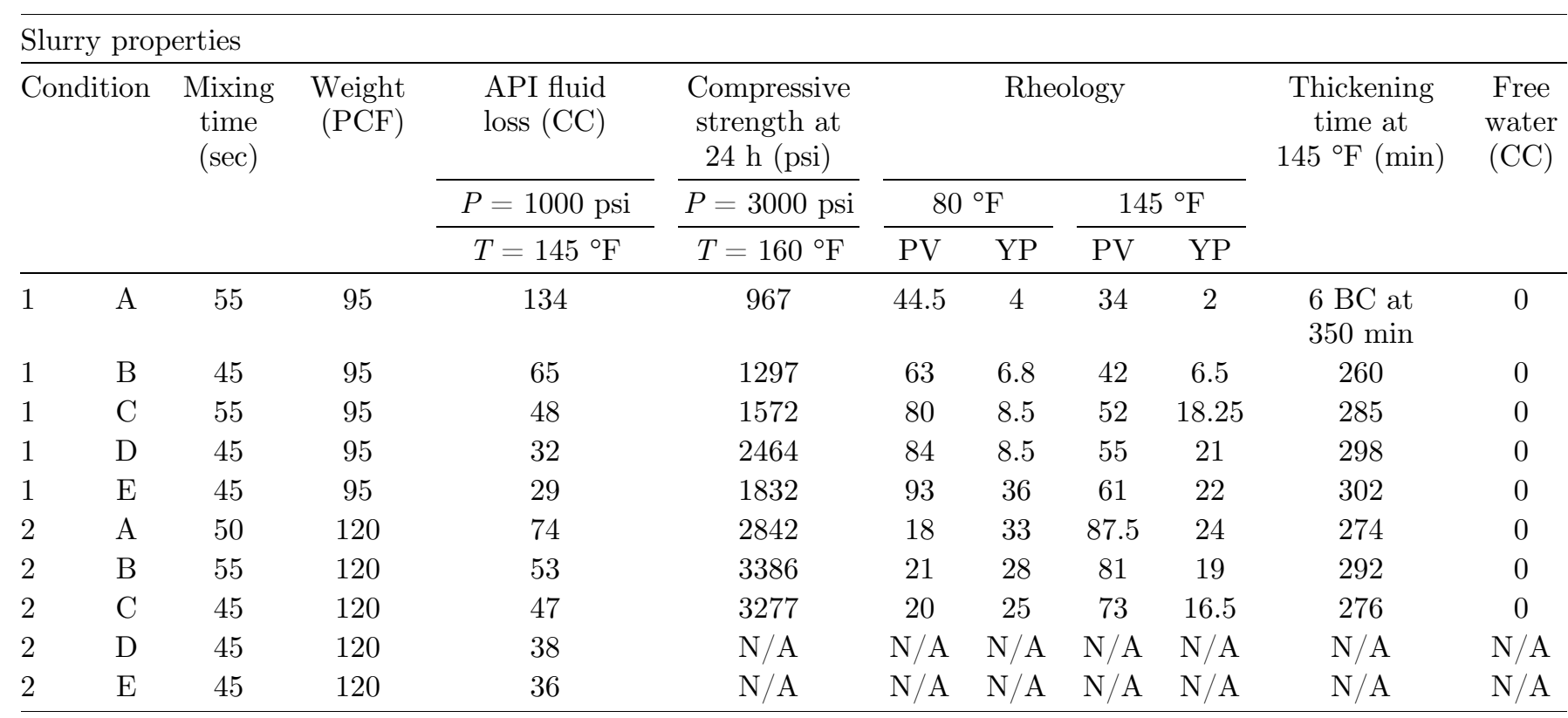

slurry in the problem of gas migration, it is necessary to measure the gel strength development profile. For this purpose, the Static Gel Strength Analyzers (SGSA) device is used. Static gel strength of well cement can be measured with a Static Gel Strength Measurement (SGSM) device. The SGSM attaches to a standard Ultrasonic Cement Analyzer (UCA). It uses a vanned bob to condition the cement slurry inside the UCA cell. During the test, the bob intermittently rotates and measures the resistance from the slurry. At the end of the test, the software provides a complete picture of the gel strength development of the cement slurry over time. As in the UCA test, the slurry is poured into the cell and after $24 \mathrm{~h}$, the result is reported as graphs.

\section{Results and discussion}

All preliminary and rheological results including plastic viscosity, yield point, thickening time and free water content at specified times are shown in Table 2.

\subsection{Condition 1: slurries with 90 PCF density}

\subsubsection{UCA results}

UCA experiments were used for evaluation of sample slurries compressive strength and their time duration is about $24 \mathrm{~h}$. Figure 2 showed UCA test results for sample 1-A (without adding nanoparticles), in which green color indicated 967 psi as the strength value that was more important.

Figure 3 showed UCA results for sample 1-D with 95 PCF density and $0.3 \%$ nanosilica content. Its graph was similar to sample 1-A in which green color indicated 2464 psi as compressive strength.
Table 3 summarized UCA results for condition 1 . According to these results, compressive strength followed an increasing pattern by increasing nanosilica content for 95 PCF slurries.

\subsubsection{FMA analysis}

Cement fluid migration analyzer realistically simulates well parameters including temperature, hydrostatic head pressure, fluid formation pressure, and the pressure gradients which drive invasive fluid flows. The FMA test cell itself is similar to an API HTHP fluid loss cell. A hollow hydraulic piston at the top of the cell is pressurized to simulate the effect of the hydrostatic pressure on the cement. Filtrate from the cement slurry can be collected from the bottom and the top of the cell through screens or rock core. The test cell can be rotated to simulate actual wellbore angles.

Figure 4 showed the results of the analysis of gas migration. According to this figure, the duration of test was between 4 and $5 \mathrm{~h}$. Gas migration amount was about $6 \mathrm{~mL}$ based on this chart.

Table 4 summarized FMA results for condition 1 . According to these results, fluid migration amounts followed a decreasing pattern by increasing nanosilica content from zero to $0.3 \%$ for $95 \mathrm{PCF}$ slurries. So for slurries with 95 PCF density, sample 1-D with 0.3 \& nanosilica showed the best result.

\subsubsection{Triaxial test and the results of Mohr circles}

Triaxial test is used to evaluate and measure the strength of cement in a well that is pressured from the three directions and is analyzed by the Mohr circle. Stress strain relationships in rocks examined the elastic behavior of rocks, which was largely reversible. By rock failure, it was meant the formation of faults and fracture planes, crushing, and 


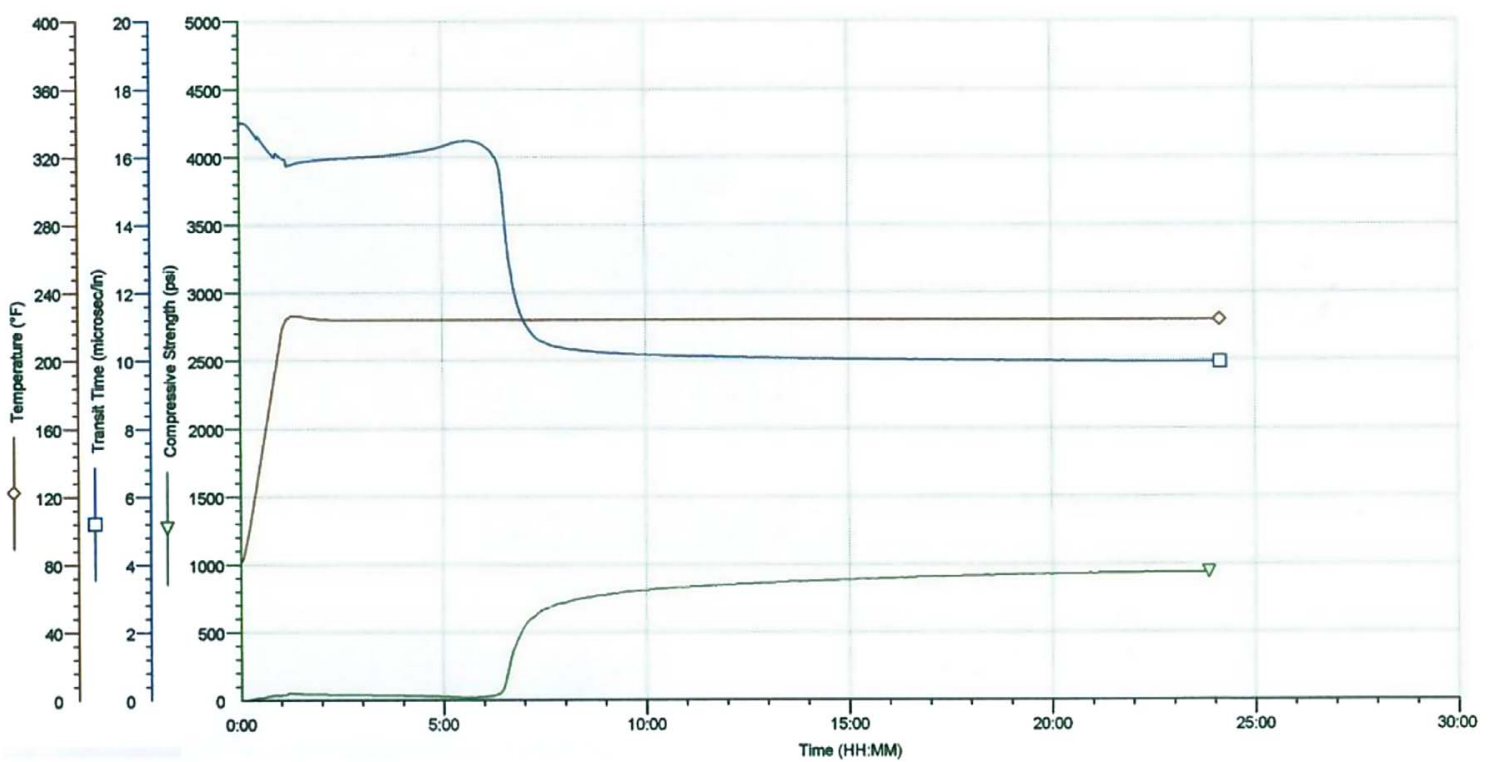

Fig. 2. UCA result for 95 PCF sample without adding nanoparticles (condition 1-A).

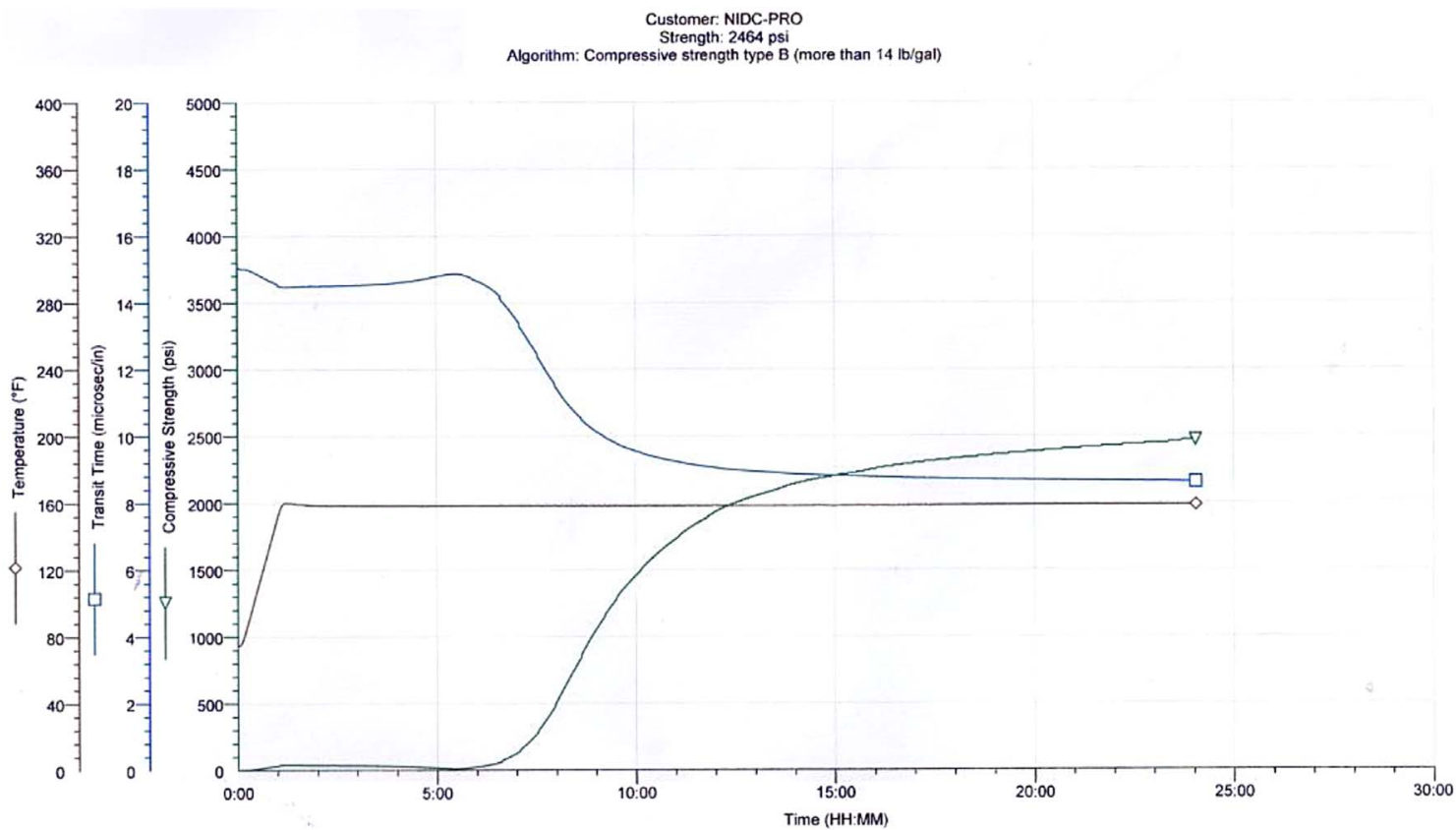

Fig. 3. UCA result for $95 \mathrm{PCF}$ with $0.3 \%$ nanoparticles (condition 1-D).

Table 3. Compressive strength comparison for condition 1 .

\begin{tabular}{lccc}
\hline Sample & Density $(\mathrm{PCF})$ & NS\% & CS (psi) \\
\hline $1-A$ & 95 & 0 & 967 \\
$1-B$ & 95 & 0.1 & 1297 \\
$1-C$ & 95 & 0.2 & 1572 \\
$1-D$ & 95 & 0.3 & 2464 \\
$1-E$ & 95 & 0.5 & 1832 \\
\hline
\end{tabular}




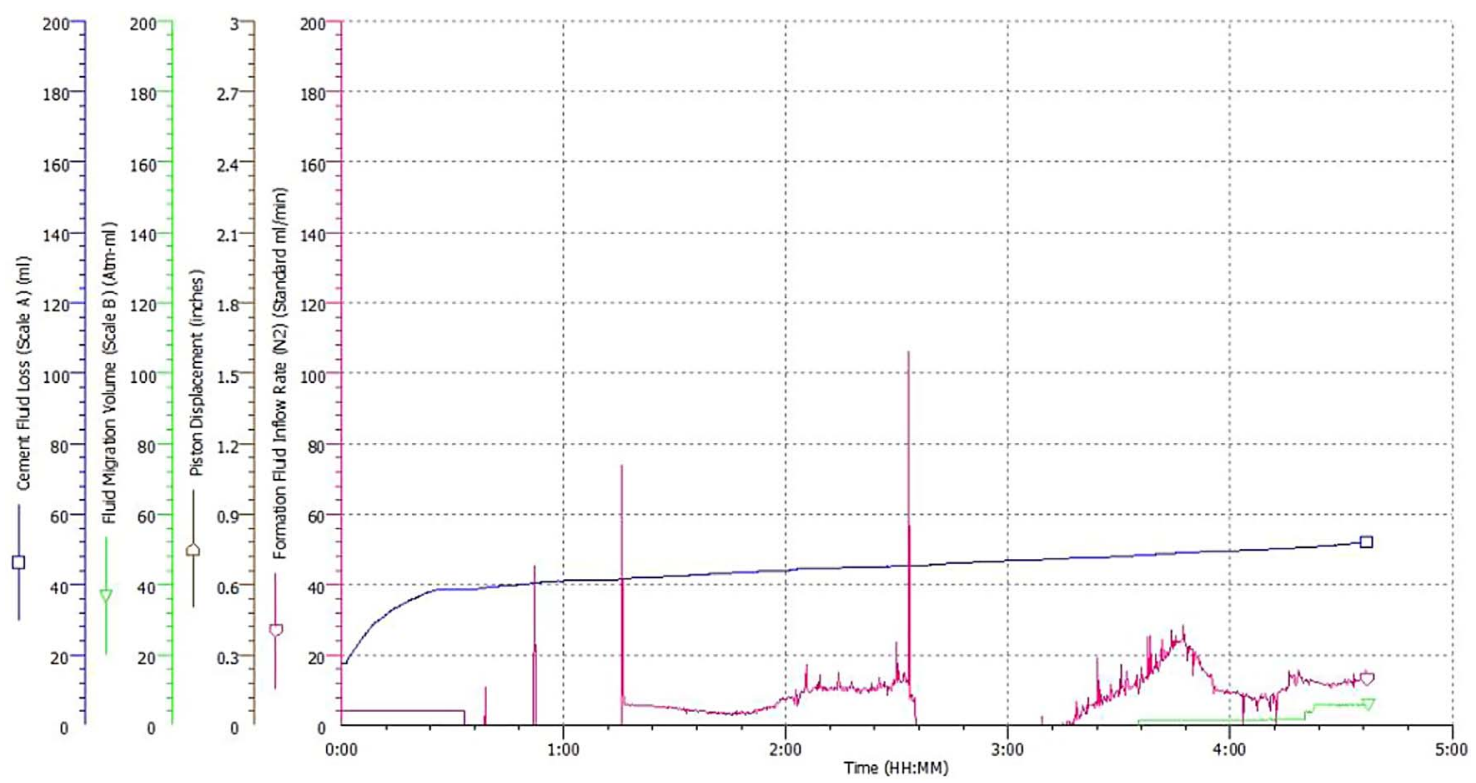

Fig. 4. Gas migration results for $95 \mathrm{PCF}$ with $0.3 \%$ nanoparticles (condition 1-D).

Table 4. Effect of NS on fluid migration at 95 PCF slurries.

\begin{tabular}{lccc}
\hline Condition & Density $(\mathrm{PCF})$ & NS\% & Migration $(\mathrm{mL})$ \\
\hline $1-\mathrm{A}$ & 95 & 0 & 76 \\
$1-\mathrm{B}$ & 95 & 0.1 & 60 \\
$1-\mathrm{C}$ & 95 & 0.2 & 28 \\
$1-\mathrm{D}$ & 95 & 0.3 & 6 \\
$1-\mathrm{E}$ & 95 & 0.5 & 17 \\
\hline
\end{tabular}

Table 5. Triaxial test data and Mohr circle results for condition 1 (95 PCF).

\begin{tabular}{lccccc}
\hline Test parameters & 1-A & 1-B & 1-C & 1-D & 1-E \\
\hline Standard & ASTM D2664 & ASTM D2664 & ASTM D2664 & ASTM D2664 & ASTM D2664 \\
Peak stress (MPa) & 28 & 31 & 36 & 42 & 37 \\
Diameter (mm) & 38.30 & 38.33 & 38.60 & 38.30 & 38.33 \\
Height $(\mathrm{mm})$ & 79.79 & 78.11 & 91.64 & 78.30 & 79.33 \\
Loading rate $(\mathrm{MPa} / \mathrm{s})$ & 0.08 & 0.08 & 0.08 & 0.08 & 0.08 \\
C (MPa) & 5.5 & 3.8 & 6 & 8 & 5.5 \\
$\Phi$ & 20 & 25 & 28 & 25 & 28 \\
\hline
\end{tabular}

relative motion of individual mineral grains and cements. Mohr circle and a linear failure envelope are the most common methods used to plot stresses and indicate strength limits. This technique predicts failure when stresses surpass both the intrinsic strength of a rock and internal friction. Considering the results, condition (1-D) showed lower amount for gas migration. So, it was planned to investigate its strength by triaxial test. Table 5 and Figure 5 show the conditions and results.
Figure 5 showed the deformation rate based on the pressure on the sample, which is known as stress on the strain, and shows $42 \mathrm{MPa}$. In this test, pressure was applied from the three directions to the sample and examines the deformation of the sample, and ultimately by Mohr circle, this deformation is analyzed.

As explained before, the Mohr circles are indicators for studying the UCA and Triaxial charts, and based on this index, the correct conclusion based on the results of the 


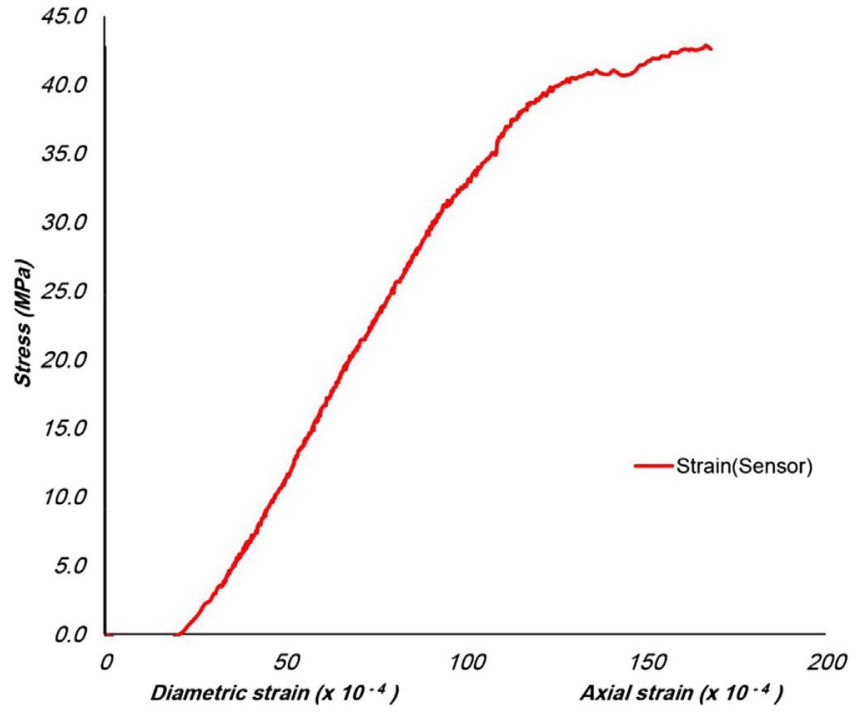

Fig. 5. Behavior of strain (sensor) for condition (1-D).

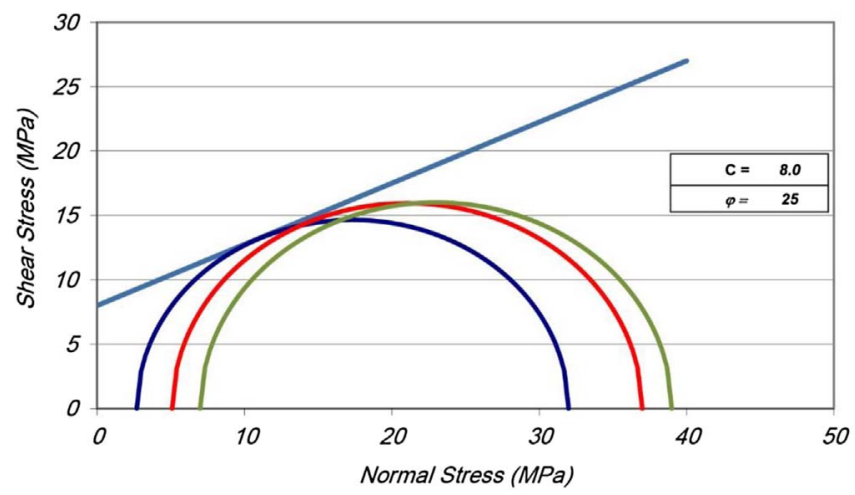

Fig. 6. Mohr circle graph for condition (1-D) based on triaxial test.

circle could be drawn. Figure 6 showed Mohr circle drawing for sample 1-D

Table 6 summarized triaxial and Mohr circle data and results for condition 1 with $95 \mathrm{PCF}$ density. As can be seen from Table 6 and the failure stress diagrams (Fig. 5), the maximum tolerable stress for cement by adding nanosilica has reached from 28 to $42 \mathrm{MPa}$, which is a sign of the positive effect of nanosilica addition. The sample with higher peak stress is more suitable. Therefore, the slurry with 95 PCF density became better by adding $0.3 \%$ nanosilica. So, program (condition 1-D), (0.3\% Nano) had the best result. Condition (1-D) showed less gas migration amount and higher peak stress.

\subsection{Condition 2: slurries with 120 PCF density}

Laboratory process started via preparation of samples and carried out preliminary experiments for slurry (2-A). The same tests were performed for samples 2-B and 2-C. But in samples 2-D and 2-E early gelation occurred and it was impossible to complete the test procedure.

\subsubsection{UCA results}

Mono-axis test is used to measure the compressive strength of cement in one direction and the stresses that cement can tolerate. According to Figure 7, slurry sample with weight of $120 \mathrm{PCF}$ without addition of nanoparticles, indicated 2842 psi for compressive strength.

Table 7 summarized UCA results for condition 2 . Besed on these results, nanosilica had positive effect on increasing compressive strength, and according to Figure 8, sample $2-\mathrm{B}$ with $0.1 \%$ nanosilica showed the best result.

\subsubsection{FMA analysis}

FMA test was used to measure gas migration and, based on this test, the amount of gas influx can be checked. FMA test for sample 2-A showed $17 \mathrm{~mL}$ as fluid migration amount. Figure 9 illustrates zero as FMA result for sample 2-B.

Table 8 summarized FMA results for condition 2 . According to these results, fluid migration amounts at sample $2-\mathrm{B}$ with $0.1 \%$ nanosilica content showed the ideal result.

Comparison of Tables 4 and 8 shows that the rate of fluid migration was at 120 PCF less than the rate of migration at $95 \mathrm{PCF}$, the reason for this could be the presence of Anti-gas migration additive in the composition of $120 \mathrm{PCF}$ slurries.

\subsubsection{Triaxial test and the results of Mohr circles}

Figure 10 illustrates behavior for sample 2-B in triaxial test. According to Figures 10 and 11 sample 2-B showed $54 \mathrm{MPa}$ as peak stress value.

Table 6. Triaxial test data and Mohr circle results for condition 1 (95 PCF).

\begin{tabular}{lccccc}
\hline Test parameters & 1-A & 1-B & 1-C & 1-D & 1-E \\
\hline Standard & ASTM D2664 & ASTM D2664 & ASTM D2664 & ASTM D2664 & ASTM D2664 \\
Peak stress (MPa) & 28 & 31 & 36 & 42 & 37 \\
Diameter (mm) & 38.30 & 38.33 & 38.60 & 38.30 & 38.33 \\
Height $(\mathrm{mm})$ & 79.79 & 78.11 & 91.64 & 78.30 & 79.33 \\
Loading rate $(\mathrm{MPa} / \mathrm{s})$ & 0.08 & 0.08 & 0.08 & 0.08 & 0.08 \\
C $(\mathrm{MPa})$ & 5.5 & 3.8 & 6 & 8 & 5.5 \\
$\Phi$ & 20 & 25 & 28 & 25 & 28 \\
\hline
\end{tabular}




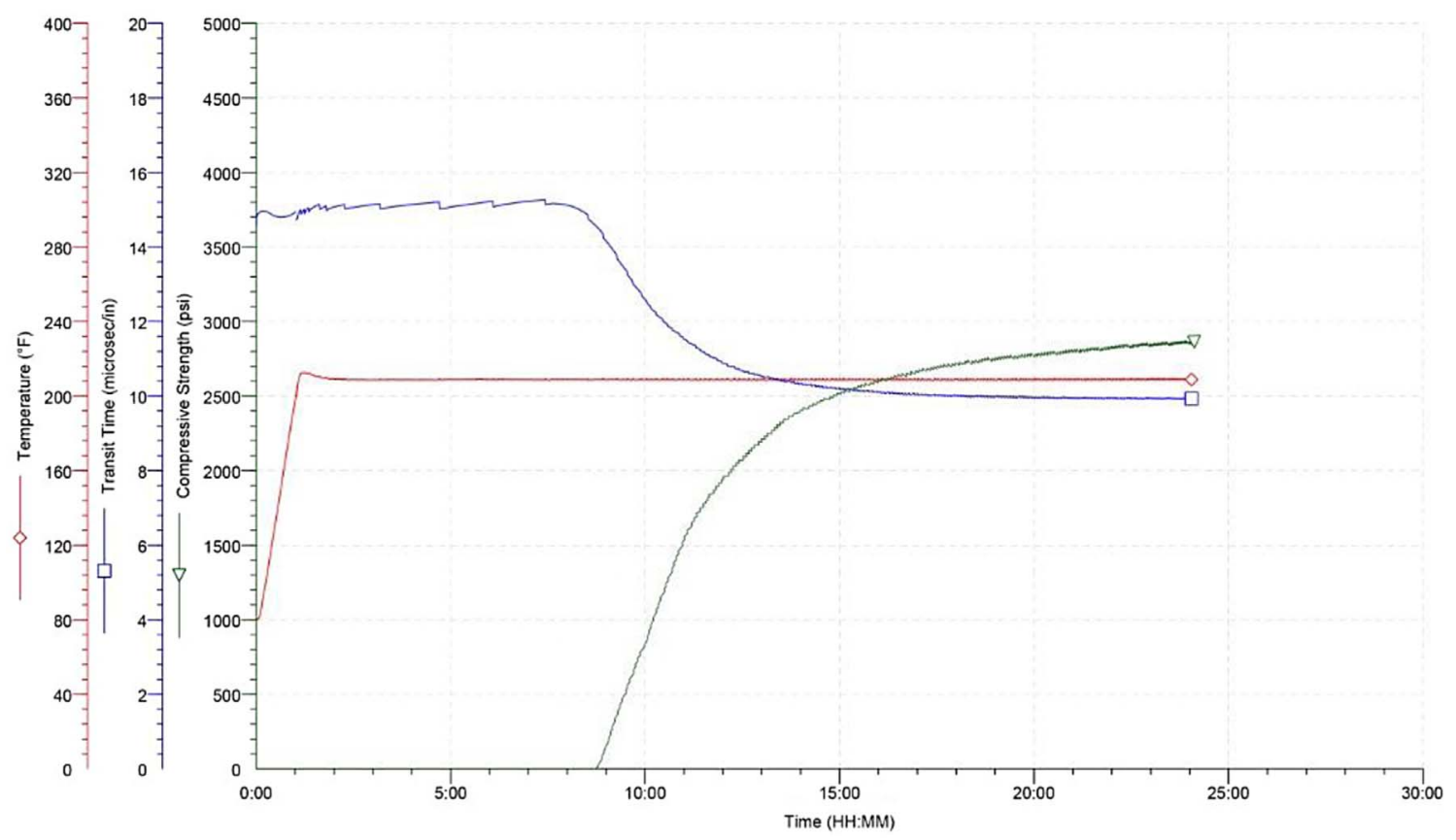

Fig. 7. UCA graph for condition (2-A) with density of 120 PCF and without nanoparticles.

Table 7. Effect of NS on compressive strength at 120 PCF slurries.

\begin{tabular}{lccc}
\hline Condition & Density $(\mathrm{PCF})$ & $\mathrm{NS} \%$ & $\mathrm{CS}(\mathrm{psi})$ \\
\hline $2-\mathrm{A}$ & 120 & 0 & 2842 \\
$2-\mathrm{B}$ & 120 & 0.1 & 3386 \\
$2-\mathrm{C}$ & 120 & 0.2 & 3277 \\
$2-\mathrm{D}$ & 120 & 0.3 & $\mathrm{~N} / \mathrm{A}$ \\
$2-\mathrm{E}$ & 120 & 0.5 & $\mathrm{~N} / \mathrm{A}$ \\
\hline
\end{tabular}

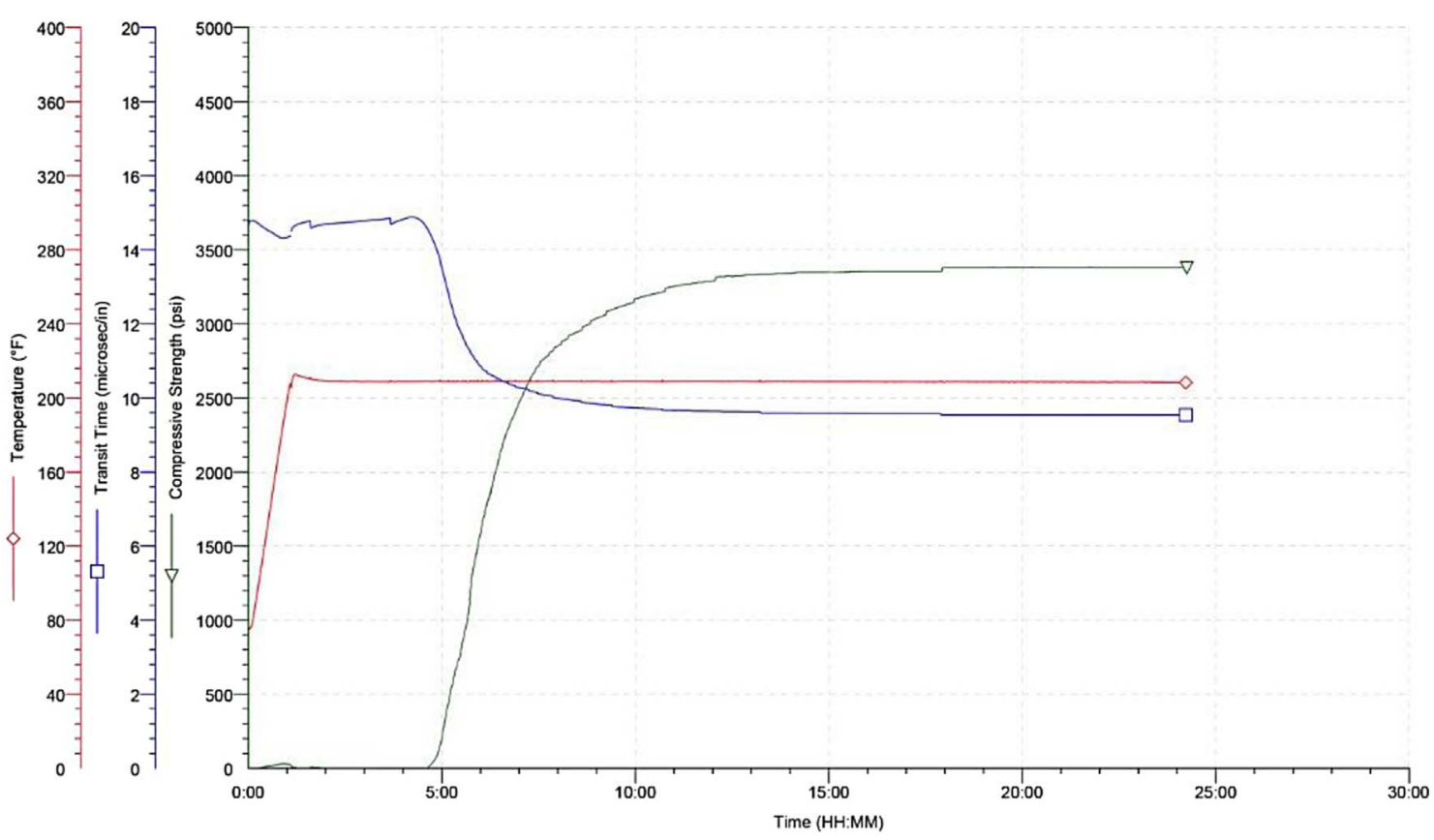

Fig. 8. UCA graph for condition (2-B) with density of 120 PCF and $0.1 \%$ nanoparticles. 


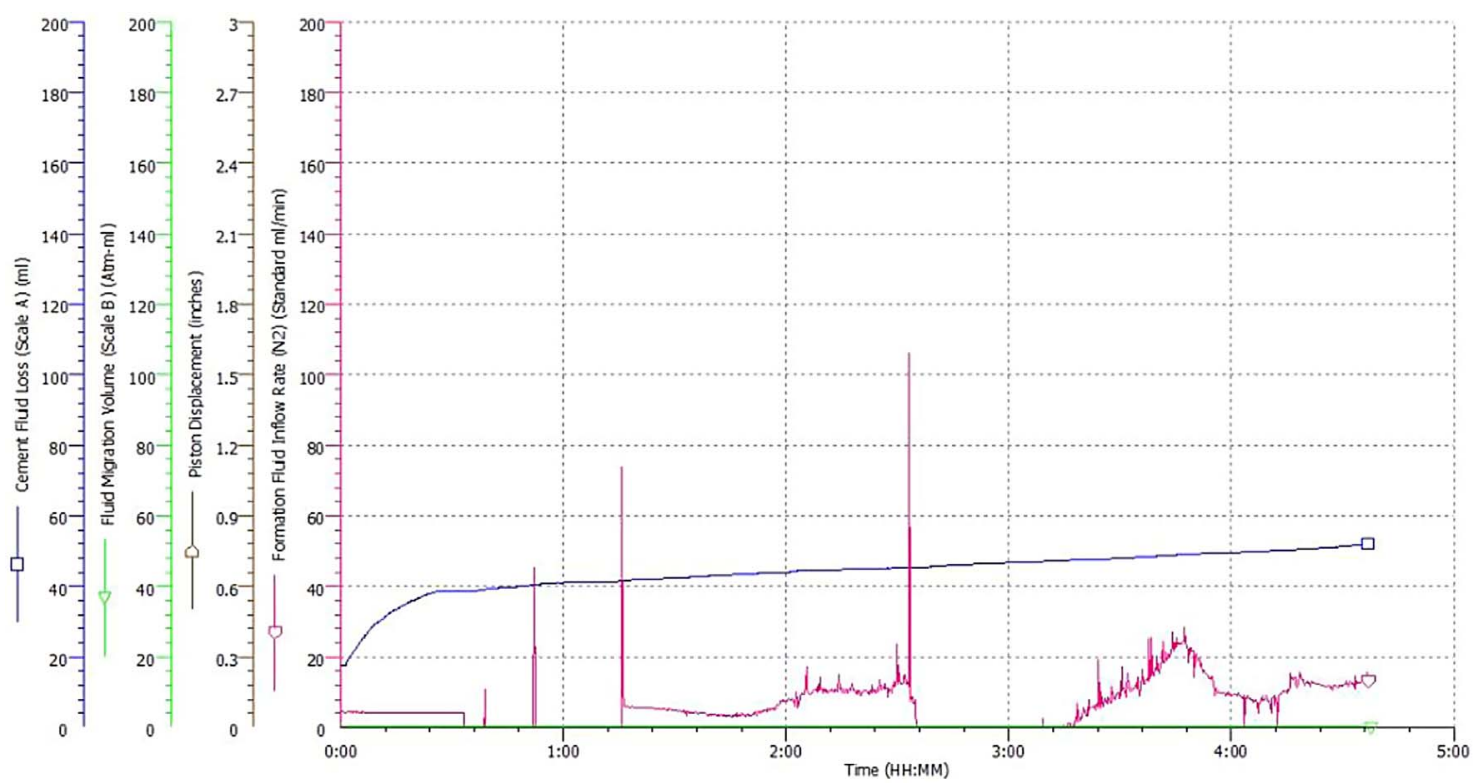

Fig. 9. FMA results for condition (2-B).

Table 8. Effect of NS on fluid migration at $120 \mathrm{PCF}$ slurries.

\begin{tabular}{lccc}
\hline Condition & Density $(\mathrm{PCF})$ & NS\% & Migration $(\mathrm{mL})$ \\
\hline $2-\mathrm{A}$ & 120 & 0 & 41 \\
$2-\mathrm{B}$ & 120 & 0.1 & 0 \\
$2-\mathrm{C}$ & 120 & 0.2 & 21 \\
$2-\mathrm{D}$ & 120 & 0.3 & $\mathrm{~N} / \mathrm{A}$ \\
$2-\mathrm{E}$ & 120 & 0.5 & $\mathrm{~N} / \mathrm{A}$ \\
\hline
\end{tabular}

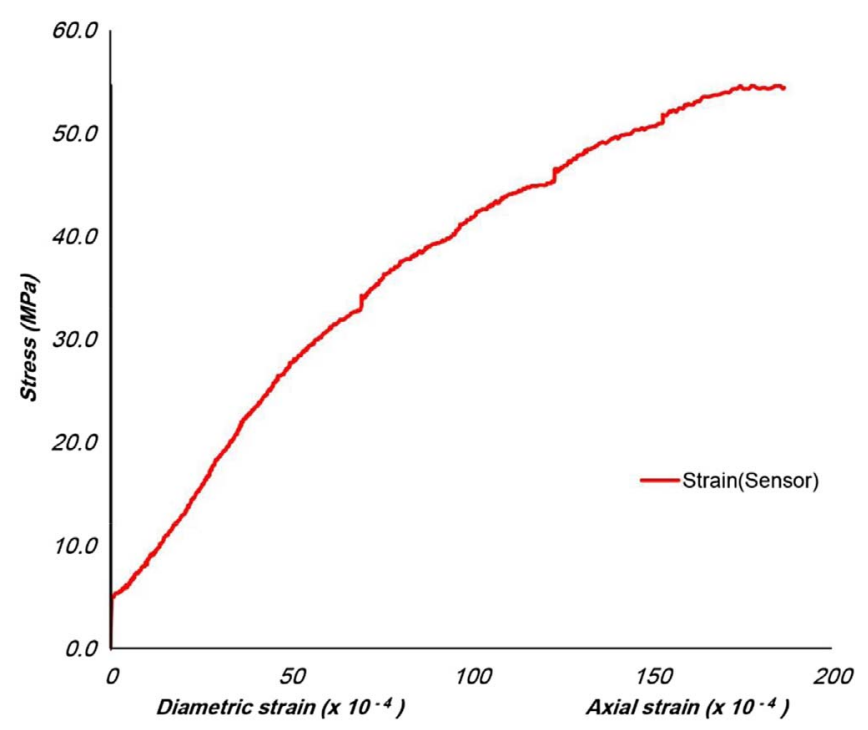

Fig. 10. Stress-strain behavior for condition (2-B).

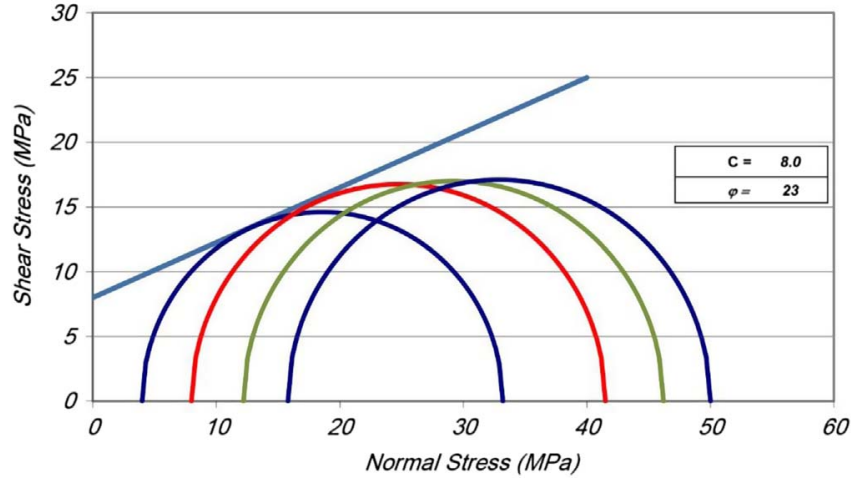

Fig. 11. Mohr circles graph for condition (2-B) based on triaxial test.

Similar to Figures 10 and 11, all data and results are summarized in Table 9. Results showed increasing in peak stress from 38 to $54 \mathrm{MPa}$ through adding nanosilica. Program (2-B) represented the best condition.

\section{Transient time measurement}

Through testing a Static Gel Strength (SGS) value equal to $500 \mathrm{lbf} / 100 \mathrm{ft}^{2}$ for gelled cement was found to be resistant against fluid invasion. The time it takes the SGS to reach $500 \mathrm{lbf} / 100 \mathrm{ft}^{2}$ from $100 \mathrm{lbf} / 100 \mathrm{ft}^{2}$ is called the transition time.

Results of the SGSA tests are presented in Figures 12 through 14. Regarding the diagrams and data for all cement slurries, there is a slight decrease in transient time via adding nanosilica. 
Table 9. Triaxial test data and Mohr circle results for condition 2 (120 PCF).

\begin{tabular}{lccccc}
\hline Test parameters & 2-A & 2-B & 2-C & 2-D & 2-E \\
\hline Standard & ASTM D2664 & ASTM D2664 & ASTM D2664 & ASTM D2664 & ASTM D2664 \\
Peak stress (MPa) & 38 & 54 & 47 & N /A & N/A \\
Diameter (mm) & 38.30 & 38.33 & 38.10 & N/A & N/A \\
Height $(\mathrm{mm})$ & 79.10 & 90.30 & 78.60 & N/A & N/A \\
Loading rate $(\mathrm{MPa} / \mathrm{s})$ & 0.08 & 0.08 & 0.08 & N/A & N/A \\
C $(\mathrm{MPa})$ & 6 & 8 & 0.8 & N/A & N $/ \mathrm{A}$ \\
$\Phi$ & 20 & 23 & 33 & N $/ \mathrm{A}$ & N/A \\
\hline
\end{tabular}

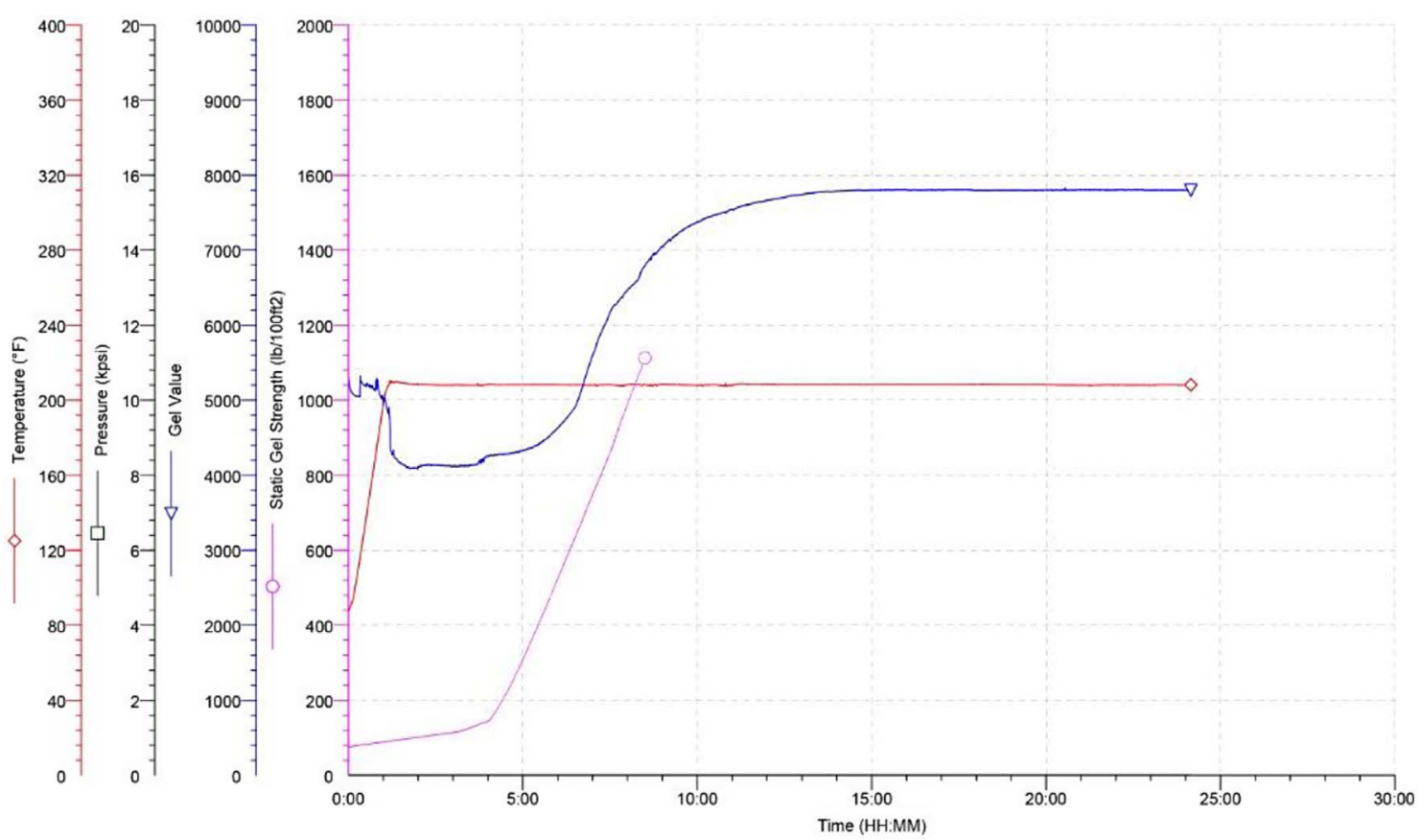

Fig. 12. SGSA graph for sample 1-A.

Table 10. Summary of SGSA test values for both densities

\begin{tabular}{lccccc}
\hline Test no. & Density PCF & NS\% & Time at 100 psi HH:MM & Time at 500 psi HH:MM & Transient time MM \\
\hline $1-\mathrm{A}$ & 95 & 0 & $02: 05$ & $05: 55$ & 230 \\
$1-\mathrm{B}$ & 95 & 0.1 & $02: 30$ & $05: 15$ & 165 \\
1-C & 95 & 0.2 & $03: 15$ & $04: 45$ & 90 \\
$1-\mathrm{D}$ & 95 & 0.3 & $03: 25$ & $04: 30$ & 65 \\
$1-\mathrm{E}$ & 95 & 0.5 & $03: 05$ & $05: 00$ & 115 \\
$2-\mathrm{A}$ & 120 & 0 & $02: 55$ & $05: 05$ & 130 \\
$2-\mathrm{B}$ & 120 & 0.1 & $03: 40$ & $04: 15$ & 35 \\
$2-\mathrm{C}$ & 120 & 0.2 & $03: 30$ & $04: 40$ & 70 \\
\hline
\end{tabular}




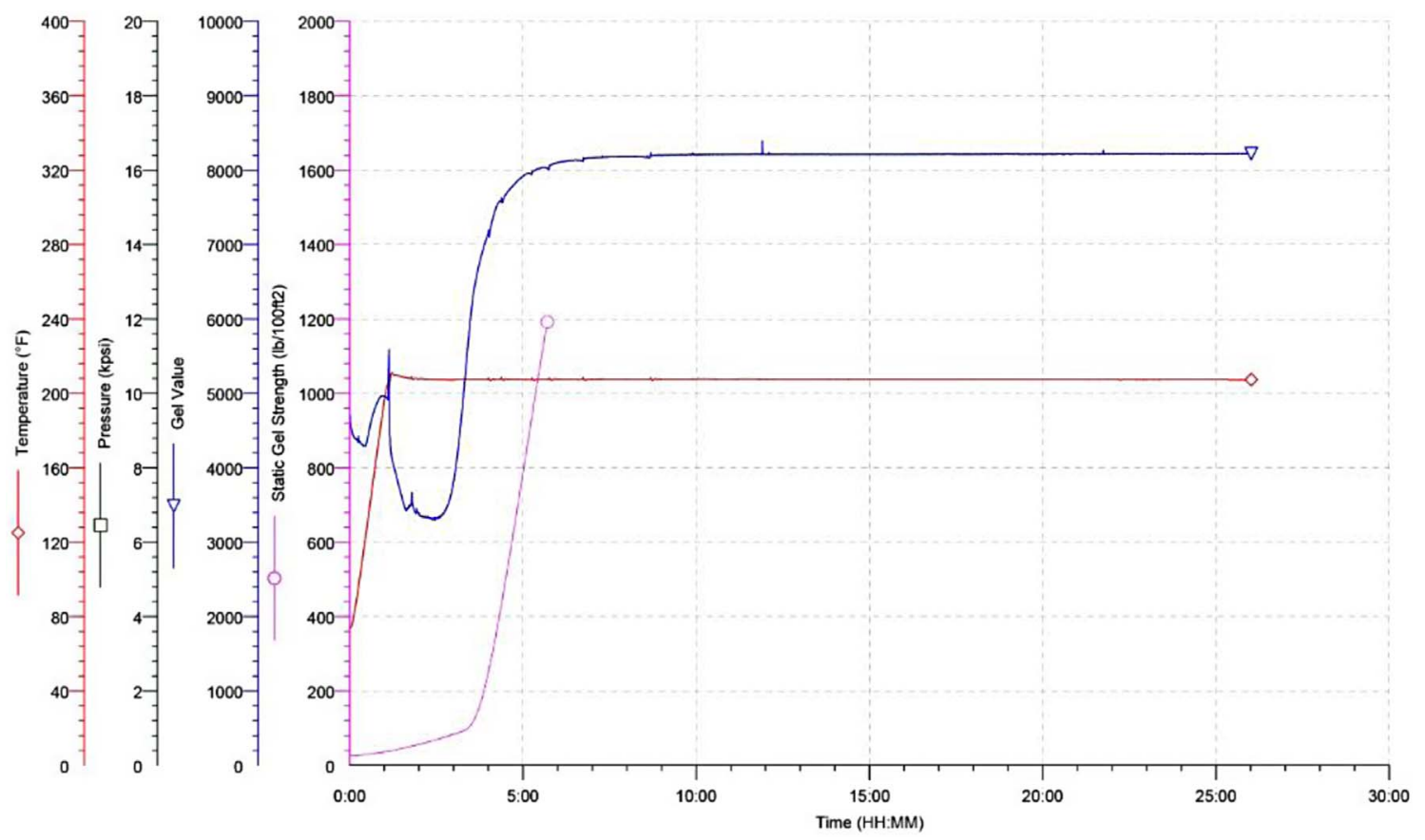

Fig. 13. SGSA graph for sample 1-D.

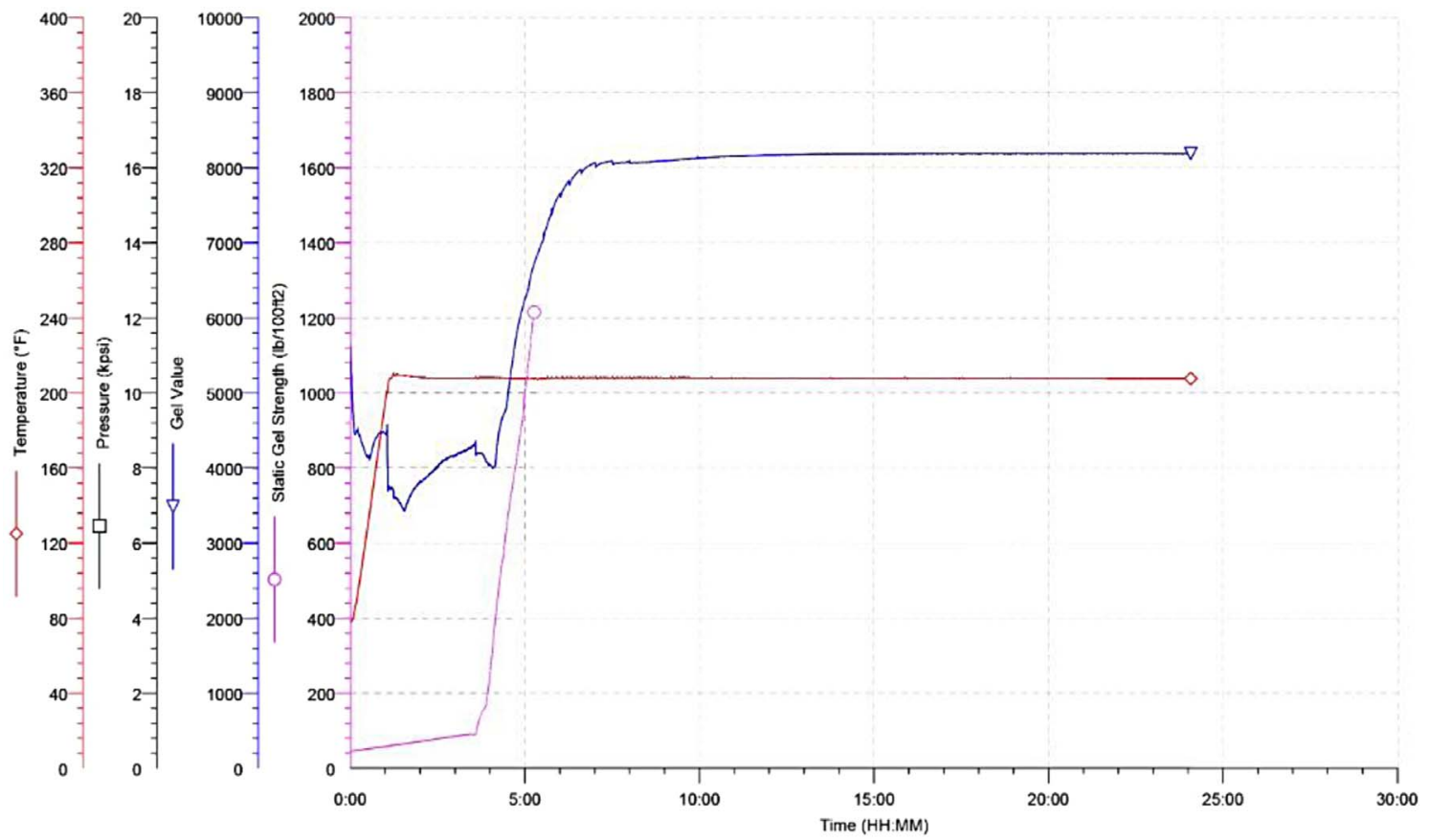

Fig. 14. SGSA graph for sample 2-B.

In Table 10, the values for the strength of 500 psi and 100 are extracted from related figures like Figures $12-14$ as SGSA diagrams and the transition time is the difference between these two values. It can be seen that in the
1-B program that contains $0.3 \%$ of nanosilica compared to the 1-A program which is nanosilica-free, the transient time is significantly reduced. Reducing the transient time means reducing the opportunity for gas to enter the pores 
in the cement block. It could be due to improvement in cement hydration stage by adding nanosilica as explained in introduction. Also, Transient time in second condition have shorter domain due to presence of Anti-gas migration additive in their composition.

\section{Conclusion}

Oil well cements can be categorized as light, moderate and heavy weight cements. Different attempts and processes are required for enhancement of their physical and chemical properties. Conventional behavior such as gel strength, compressive strength, and complementary properties of cement slurry like transient time and resistance against fluid migration, were improved via adding optimum percentage of nanosilica. According to the experiments, the followings are concluded:

- Nanosilica does not have significant effect on free water, fluid loss, and thickening time.

- Effect of nanosilica on light weight cement is more considerable rather than of moderate cement.

- By increasing of cement weight, optimum Nano percentage was decreased from $0.3 \%$ to $0.1 \%$.

- Nanosilica increased compressive strength of cement slurry.

- Nanosilica decreased fluid migration in cement slurry, especially in optimum percentage of nanoparticles.

- Nanosilica improved compressive strength of cement, Mohr circles validated it.

- It is expected that researchers investigate other Nanoparticles like Nano hematite on different weights of cement slurry, also on different formulas of slurry composition.

\section{References}

1 Bayanak M., Zarinabadi S., Shahbazi K. (2019) Experimentation optimization of effective parameters on fluid migration in drilling cement slurry in well hydrocarbon, Noor Publishing, Iran.

2 Cadix A., Thant K., Neufeld J., Nelson T., Auneau L., Phan C., Wilson J. (2017) Short term gas migration control in well cementing: Comparative behavior of fluid loss control polymers, in: SPE International Conference on Oilfield Chemistry, 201\%, Society of Petroleum Engineers, Montgomery, Texas, USA, 19 p. doi: 10.2118/184564-MS.

3 Vu M.H., Bois A.P., Badalamenti A. (2018) Gas migration modeling to prevent sustained casing pressure and casing vent flow, in: SPE/IADC Middle East Drilling Technology Conference and Exhibition, 2018, Society of Petroleum Engineers, Abu Dhabi, UAE, 24 p.

4 Stone W.H., Christian W.W. (1974) The inability of unset cement to control formation pressure, in: SPE Symposium on Formation Damage Control, 1974, Society of Petroleum Engineers.

5 Cooke C.E. Jr., Kluck M.P., Medrano R. (1983) Field measurements of annular pressure and temperature during primary cementing, J. Pet. Technol. 35, 8, 1429-1438. SPE11206-PA.

6 Garcia J., Clark C. (1976) An investigation of annular gas flow following cementing operations, in: SPE Symposium on Formation Damage Control, 1976, Society of Petroleum Engineers.

7 Al-Buraik K., Al-Abdulqader K., Bsaibes R. (1998) Prevention of shallow gas migration through cement, in: IADC/SPE Asia Pacific Drilling Technology Conference, Jakarta, Indonesia, 7-9 September 1998. SPE-47775-MS. doi: 10.2118/47775-MS.

8 Parcevaux P., Sault P. (1984) Cement shrinkage and elasticity: a new approach for a good zonal isolation, in: SPE Annual Technical Conference and Exhibition, 1984, Society of Petroleum Engineers.

9 Cheung P., Beirute R.M. (1985) Gas flow in cements, J. Pet. Technol. 37, 6, 1041-1048.

10 Levine D.C., Thomas E.W., Bezner H.P., Tolle G.C. (1979) Annular gas flow after cementing: A look at practical solutions, in: SPE Annual Technical Conference and Exhibition, 1979, Society of Petroleum Engineers. doi: 10.2118/8255-MS.

11 Bour D., Wilkinson J. (1992) Combating gas migration in the Michigan basin, SPE Drill. Eng. 7, 1, 65-71.

12 Tinsley J.M., Miller E.C., Sabins F.L., Sutton D.L. (1980) Study of factors causing annular gas flow following primary cementing, J. Pet. Technol. 32, 8, 1427-1437. doi: 10.2118/ 8257-PA.

13 Stewart R., Schouten F. (1988) Gas invasion and migration in cemented annuli: Causes and cures, SPE Drill. Eng. 3, 1, 77-82.

14 Watters L.T., Sabins F.L. (1980) Field evaluation of method to control gas flow following cementing, in: SPE Annual Technical Conference and Exhibition, 1980, Society of Petroleum Engineers.

15 Seidel F., Greene T. (1985) Use of expanding cement improves bonding and aids in eliminating annular gas migration in Hobbs Grayburg-San Andres wells, in: SPE Annual Technical Conference and Exhibition, 1985, Society of Petroleum Engineers.

16 Guangchao D., Honghua L., Hongjuan O., Jie L. (2016) Study on gas migration prevention of cementing slurry improved by surfactant, Petrochem. Ind. Technol. 2016, 5, 40.

17 Bhattacharjee G., Barmecha V., Kushwaha O.S., Kumar R. (2018) Kinetic promotion of methane hydrate formation by combining anionic and silicone surfactants: Scalability promise of methane storage due to prevention of foam formation, J. Chem. Thermodyn. 117, 248-255. doi: 10.1016/j.jct.2017. 09.029 .

18 Sutton D., Ravi K. (1989) New method for determining downhole properties that affect gas migration and annular sealing, in: SPE Annual Technical Conference and Exhibition, 1989, Society of Petroleum Engineers.

19 Kwatia G., Al R.M., Salehi S., Teodoriu C. (2019) Enhanced cement composition for preventing annular gas migration, in: ASME 2019 38th International Conference on Ocean, Offshore and Arctic Engineering, American Society of Mechanical Engineers Digital Collection. doi: 10.1115/ OMAE2019-95589.

20 Wilkins R.P., Free D. (1989) A new approach to the prediction of gas flow after cementing, in: SPE/IADC Drilling Conference, New Orleans, Louisiana, 28 February-3 March 1989. SPE-18622-MS. doi: 10.2118/18622-MS

21 Thakkar A., Raval A., Chandra S., Shah M., Sircar A. (2020) A comprehensive review of the application of nano-silica in oil well cementing, J. Pet. 6, 2, 123-129. doi: 10.1016/j. petlm.2019.06.005. 
22 Wojtanowicz A.K., Smith J.R., Novakovic D., Chimmalgi V.S., Newman K.R., Dusterhoft D., Gahan B. (2002) Cement pulsation treatment in wells, in: SPE Annual Technical Conference and Exhibition. doi: 10.2118/77752-ms.

23 Moritis G. (2008) SWP advances CO2 sequestration ECBM EOR demos, Oil Gas J. 106, 37, 60-63.

24 Dean G.D., Brennen M.A. (1992) A unique laboratory gas flow model reveals insight to predict gas migration in cement, in: SPE Western Regional Meeting, Bakersfield, California 30 March-1 April 1992. SPE-24049-MS. doi: 10.2118/24049-MS.

25 Ahmed S., Ezeakacha C.P., Salehi S. (2018) Improvement in cement sealing properties and integrity using conductive carbon nano materials: From strength to thickening time, in: SPE Annual Technical Conference and Exhibition, Dallas, Texas, USA, 24-26 September 2018. SPE-191709-MS, doi: 10.2118/191709-MS.

26 Abbas G., Irawan S., Kumar S., Kalwar S.A. (2014) Experimental study of gas migration prevention through cement slurry using hydroxypropylmethylcellulose, in: IADC/SPE Asia Pacific Drilling Technology Conference, Bangkok, Thailand, 25-27 August 2014. SPE-170538-MS. https://doi-org.ezproxy.lib.ou.edu/10.2118/170538-MS

27 King G.E., King D.E. (2013) Environmental risk arising from well-construction failure-differences between barrier and well failure and estimates of failure frequency across common well types, locations, and well age, SPE Prod. Oper. 28, 4, 323-344. SPE-166142-PA. doi: 10.2118/166142-PA.

28 Griffin T., Spangle L., Nelson E. (1979) New expanding cement promotes better bonding, Oil Gas J. 77, 26, 143.

29 Němeček J., Li L., Xi Y. (2017) Electrokinetic nanoparticle injection for remediating leaks in oil well Cement, Constr. Build. Mater. 156, 63-72. doi: 10.1016/j.conbuildmat.2017. 08.152 .

30 Goboncan V.C., Dillenbeck R.L. (2003) Real-time cement expansion/shrinkage testing under downhole condition for enhanced annular isolation, in: SPE/IADC Drilling Conference. doi: 10.2118/79911-ms.

31 Mata C., Calubayan A. (2016) Use of hollow glass spheres in lightweight cements - selection criteria, in: SPE - Asia Pacific Oil \& Gas Conference and Exhibition. doi: 10.2118/ 82399-ms.

32 Al-Yami A.S., Al-Humaidi A.S. (2016) High density cement formulation to prevent gas migration problems. Google Patents 2016. doi: 10.2118/187700-MS.

33 Al-Yami A.S. (2015) An Innovative cement formula to mitigate gas migration problems in deep gas wells: Lab studies and field cases, in: SPE Kuwait Oil $\mathcal{E}$ Gas Show and Conference, Mishref, Kuwait, 11-14 October 2015. doi: 10.2118/175194-MS.

34 Pour M.M., Moghadasi J. (2007) New cement formulation that solves gas migration problems in Iranian South Pars field condition, in: SPE Middle East Oil and Gas Show and Conference, Society of Petroleum Engineers. doi: 10.2523/ 105663-MS.

35 Lackey G., Rajaram H., Sherwood O.A., Burke T.L., Ryan J.N. (2017) Surface casing pressure as an indicator of well integrity loss and stray gas migration in the Wattenberg Field Colorado, Environ. Sci. Technol. 51, 6, 3567-3574.

36 Nelson E.B., Guillot D. (2006) Well cementing, 2nd edn., Schlumberger, Sugar Land, Texas, USA.

37 API (2011) 10A-specification for cements and materials for well cementing, Tech. Rep., American Petroleum Institute.
38 ASTM (2010) C465-standard specification for processing additions for use in the manufacture of hydraulic cements, Tech. Rep.

39 ASTM (2007) C150-Standard specification for Portland cement, Tech. Rep.

40 Chinh N.H., Son N.H., Son D.V., Be N.V., Thuan N.V. (2015) Casing and cementing with potential gas influx, Petro Vietnam 6, 27-32.

41 Al-Ramadan M., Salehi S., Teodoriu C. (2019) Enhanced cement composition for preventing annular gas migration, in: ASME 38th International Conference on Ocean Offshore and Arctic Engineering, Glasgow, Scotland, UK, 9-14 June 2019. OMAE 2019-95589.

42 Guo R., Chen Y., Cotinho R.P., Waltrich P.J. (2017) Numerical and experimental investigation of gas kick migration during casing while drilling, in: SPE Health, Safety, Security, Environment $\&$ Social Responsibility ConferenceNorth America, New Orleans, Louisiana, USA, 18-20 April 2017. SPE-184416-MS. doi: 10.2118/184416-ms.

43 Nelson E.B. (1990) Well Cementing, , Newnes, Vol. 28.

44 Sanchez F., Sobolev K. (2010) Nanotechnology in concrete A review, Constr. Build. Mater. 24, 2010, 2060-2071. doi: 10.1016/j.conbuildmat.2010.03.014.

45 Santra A., Boul P.J., Pang X. (2012) Influence of nanomaterials in oilwell cement hydration and mechanical properties, in: SPE International Oilfield Nanotechnology Conference and Exhibition, Noordwijk, The Netherlands, 12-14 June 2012. SPE 156937. doi: 10.2118/156937-ms.

46 Ershadi V., Ebadi T., Rabani A.R., Ershadi L., Soltanian H. (2011) The effect of nano-silica on cement matrix permeability in oil well to decrease the pollution of receptive environment, Int. J. Environ. Sci. Develop. 2, 2, 128-132. doi: 10.7763/ijesd.2011.v2.109.

47 Fakoya M.F., Shah S.N. (2017) Emergence of nanotechnology in the oil and gas industry: Emphasis on the application of silica nanoparticles, J. Pet. 3, 4, 391-405. doi: 10.1016/j.petlm. 2017.03.001.

$48 \mathrm{Li}$ Z., Vandenbossche J., Iannacchione A., Brigham J., Kutchko B. (2016) Theory-based review of limitations with static gel strength in cement/matrix characterization, SPE Drill. Comp. 31, 2, 145-158. doi: 10.2118/178923-pa.

49 Rai S., Tiwari S. (2018) Nano silica in cement hydration, Mater. Today Proc. 5, 3, 9196-9202. doi: 10.1016/j.matpr. 2017.10.044.

50 Quercia G., Brouwers H.J.H. (2010) Application of nanosilica (nano silica) in concrete mixtures, in: 8th Fib PhD Symposium in Kgs, Lyngby, Denmark.

51 Zhang J., Weissinger E.A., Peethamparan S., Scherera G.W. (2010) Early hydration and setting of oil well cement, Cem. Concr. Res. 40, 7, 1023-1033. doi: 10.1016/j.cemconres. 2010.03.014.

52 Lin K.L., Chang W.C., Lin D.F., Luo H.L., Tsai M.C. (2008) Effects of nano- $\mathrm{SiO}_{2}$ and different ash particle sizes on sludge ash-cement mortar, J. Environ. Manage. 88, $708-714$.

53 Qing Y., Zenan Z., Deyu K., Rongshen C. (2007) Influence of nano-SiO $\mathrm{S}_{2}$ addition on properties of hardened cement paste as compared with silica fume, Constr. Build. Mater. 21, 3, 539-545. doi: 10.1016/j.conbuildmat.2005.09.001.

54 Gaitero J.J., Campillo I., Guerrero A. (2008) Reduction of the calcium leaching rate of cement paste by addition of silica nanoparticles, Cem. Concr. Res. 38, 1112-1118. 
55 Kleef V.R.P.A.R., Vliet V.J.P.M. (1993) Improving the reliability of cement-setting-time tests by taking into account the influence of shear, SPE Drill. Comp. 8, 1, 51-56. doi: 10.2118/20926-pa.

56 Soltanian H., Mortazavi A.R. (2016) The use of nano accelerator in cement slurries in low temperature well conditions, J. Pet. Sci. Technol. 6, 1, 109-114. doi: 10.22078/jpst.2016.574.

57 Setiati N.R. (2017) Effects of additional nano-silica of compressive strength on mortar, IOP Conf. Ser. Mater. Sci. Eng. 2017, 223, 012065. doi: 10.1088/1757-899x/223/1/ 012065 . 